\title{
In silico analysis of plant phytochemicals against secreted aspartic proteinase enzyme of Candida albicans
}

\author{
S. S. Meenambiga*, R. Venkataraghavan and R. Abhishek Biswal \\ Department of Bio-Engineering, School of Engineering, Vels Institute of Science, Technology and Advanced Studies (VISTAS), Chennai, India.
}

\section{ARTICLE INFO \\ Received on: 03/09/2018 \\ Accepted on: 23/10/2018 \\ Available online: $30 / 11 / 2018$}

\author{
Key words: \\ Candida albicans, secreted \\ aspartic proteinase (SAP), \\ phytochemicals, in silico, \\ AutoDock.
}

\begin{abstract}
Candida albicans, a polymorphic fungal species of human microflora, is pathogenic and known to cause immense damage to the host organism which includes biofilm formation, oral and skin infections in immune deficient individuals. Secreted aspartic proteinase (SAP) enzyme plays a major role in promoting virulence to C. albicans, and thus could be established as a drug target for Candida infections. As a result, inhibiting the enzyme's active center using phytochemicals would reduce the severity of the enzyme's virulence. The present work focuses on the in silico analysis of about 15 plant phytochemicals against the SAP enzyme using the AutoDock 4.2.6 software. The docking results were found to be promising with emodin having the highest binding score of $-6.44 \mathrm{kCal} / \mathrm{mol}$ followed by the isoflavonoid equol with the binding score of $-6.29 \mathrm{kCal} / \mathrm{mol}$. Thus, these bioactive compounds could be used as leads for drugs targeting SAP enzymes in treating resistant Candida infections.
\end{abstract}

\section{INTRODUCTION}

Candida are group opportunistic pathogenic yeast. Candida sp. is found in the diverse ecological niche throughout the earth. Because of their significant adaptive evolutionary biochemical mechanism, they also survive as endophytic fungi in several plants and also in the human gut microflora (Moore et al., 2011). On an average, $40 \%-50 \%$ of these species are found in the gut and the oral microflora of a normal human being. These fungal species occur as commensal that depend on the host for shelter and nutrition and does not cause any damage to them and are capable of causing irreversible pathogenic effects in immunocompromised host organism such as candidiasis. The fungal kingdom is often characterized by their biochemical pathways secreted by them (Keller et al., 2005). These fungi are often ranked at the top for their ability to cause nosocomial infections (Sydnor and Perl, 2011). More often, these fungi are much known to cause skin infections and oral infections and

${ }^{*}$ Corresponding Author

S. S. Meenambiga, Department of Bio-Engineering, School of Engineering, Vels Institute of Science, Technology and Advanced Studies (VISTAS), Chennai, India.E-mail: meenambiga.se@velsuniv.ac.in are capable of forming biofilms that cause severe effects on the host. This biofilm forming ability of the organism is due to the biochemical pathway that involves the secretion of virulence enzyme called secreted aspartic proteinases (SAP). The biofilm formation occurs in the following ways: (1) yeast-forms cells that attach to the substrate, (2) the intermediate step, which involves the formation of microcolonies to produce hyphae and mycelium, (3) the maturation step, which involves the accumulation of extracellular matrix from the organism like proteoglycans, and (4) biofilm formation by colonization of yeast-form cells.

The important factor responsible for virulence caused by microorganism is the secretion of the hydrolytic enzyme. These enzymes play a major role in the pathogenesis (Barth and Gaillardin, 1997). Even though there are several enzymes, the proteinase is the most responsible for virulence factor. The proteinases are protein or peptide bond degrading enzymes and cleave the important proteins. These enzymes catalyze the hydrolysis process, thus breaking the peptide bonds. Proteinases are classified into four categories, based on their mechanism of the catalytic reaction, namely (1) serine proteinase, (2) cysteine proteinase, (3) aspartyl proteinase, and (4) metalloproteinase.

Candida albicans secretes three different hydrolytic enzymes namely secreted aspartyl proteinase, lipases, and 
phospholipase B (Monod et al., 1994). The secretion of aspartic proteinases by $\mathrm{C}$. albicans was determined to be one of the virulence determinants for different types of candidiasis. SAPs enable hyphae formation, adhesion, and phenotypic switching; digestion of the host cell membranes and evading host immune responses by degrading and inactivating the central human complement system. Therefore, an agent capable of inhibiting production of $C$. albicans SAPs will be useful in treating Candida infections. Diverse Candida species apart from $C$. albicans have shown the potential to produce the SAP proteins such as Candida dubliniensis, Candida tropicalis, and Candida parapsilosis. Candida tropicalis contains four SAP genes, C. parapsilosis contains two SAP genes, and C. dubliniensis possesses nine SAP genes in their genome (De Viragh et al., 1993; Gilfillan et al., 1998; Naglik et al., 2003). Candida albicans secretes an extracellular proteolytic enzyme called SAP. The SAP is the constitution of 10 enzymes ranging from SAP1 to SAP10 (Borelli et al., 2008). Each of these enzymes possesses the virulence activity. The SAPs are used to degrade foreign tissue and evade the host defence mechanism (Lan et al., 2004). Strains of C. albicans with deleted SAP1, SAP2, and SAP3 are less virulent and caused little damage to the in vitro model (Schaller et al., 1999).

The SAP5 enzyme of the SAP family is more prone to cause virulence. SAP enzyme performs the role of digesting molecules in order for the acquisition of nutrients, disrupting the host cell membrane for invasion and tissue damage, and attack the immune system in order to escape the antimicrobial attack from the host organism (Zaugg et al., 2011). The current study was aimed to study the drug-likeness and molecular docking of natural plant phytochemicals against the active site of $C$. albicans SAP enzyme by in silico approach. This work would be an initiative for developing plant phytochemicals as leads for C. albicans treatment.

The active center of the virulent enzyme SAP can be inhibited by natural plant phytochemicals. The phytochemicals are plant's secondary metabolites that are not directly involved in the growth and development of the plant but instead they have several medicinal properties such as antimicrobial, anticancer, antitoxic, and anti-diabetic properties (Raut and Karuppayil, 2016). Plant phytochemicals act as a potential inhibitor for inhibiting the active site of the enzyme by competing with the substrate, thereby neutralizing the effects of the virulence responsible enzyme. Several plant extracts such as methanol in hydroalcoholic and ethyl acetatemethanol leaf extracts from the plant Schinus terebinthifolius have shown the potential to inhibit Candida biofilm formation. Thin layer chromatography analysis revealed the presence of alkaloids, terpenoids, phenols, and anthraquinones (Alves et al., 2013). Ethylacetate and methanol extracts of stem bark from Croton urucurana have shown to inhibit $C$. albicans biofilm formation. Similarly, ethyl-acetate extracts of flower buds from Syzygium aromaticum are good potential inhibitors of Candida biofilms . In addition to the crude extracts, plant phytochemicals such as terpenoids, alkaloids, and flavonoids have been reported to show good $C$. albicans biofilm inhibitory activity (Raut and Karuppayil, 2016). The phytochemical baicalein inhibited about $70 \%$ of $C$. albicans biofilm on prosthetic surfaces (Cao et al., 2008). The phytochemicals such as curcumin, sesquiterpenes, and purpurin have shown good Candida biofim inhibition in various studies (Shahzad et al., 2014; Tsang et al., 2012; Xie et al., 2015)
Lipinski's rule of five is used to assess the drug likeliness and durability of a phytochemical or chemical compound (Benet et al., 2016). This rule gives the description about the molecular properties that are essential for the pharmacokinetic property of a drug (Lipinski et al., 2012). Therefore, Lipinski's rule of five is essential for a phytochemical to be used as an oral drug. Phytochemicals that satisfy the Lipinski's rule are subjected to docking studies.

\section{MATERIALS AND METHODS}

\section{Bioactive compounds from plant secondary metabolites}

The following are the plant phytochemicals obtained from the various PubMed Literatures: (1) apigenin, (2) baicalein, (3) cianidanol, (4) curcumin, (5) emodin, (6) equol, (7) genistein, (8) gingerol, (9) kaempferol, (10) myricetin, (11) pachypodol, (12) quercetin, (13) resveratrol, (14) silymarin, and (15) taxifolin. These phytochemicals have shown anti-Candidal activity cited in PubMed Literatures, and thus were selected to study the mode of interations of these compounds with the active site of $C$. albicans SAP5 enzyme. The information about the above-mentioned phytochemicals such as structure, molecular formula, and chemical formula were retrieved from the PubChem database is tabulated in Table 1. Lipinski's rule of five parameters such as molecular weight, $\log \mathrm{P}$, number of hydrogen bond donors, number of hydrogen bond acceptors, and molar refractivity were taken from the PubChem database for the above-mentioned phytochemicals. Table 2 represents the information about Lipinski's rule of various phytochemicals.

\section{SAP5 protein structure}

The three-dimensional protein structure of SAP5 was retrieved from the protein data bank (PDB) protein database. The obtained 3D structure is depicted in Figure 1. The PDB is a world renowned online open access database that provides the user about the structure, functions, and properties of various macromolecules like nucleic acids (Berman et al., 2002). The PDB ID of the SAP5 protein is $2 \mathrm{QZX}$. The water molecules were removed from the protein macromolecule for effective ligand binding. SAP5 is one of the 10 acidic hydrolases that possesses a molecular weight of 37 $\mathrm{KDa}$ and is active at a $\mathrm{pH}$ of 3.0-7.0 (Aoki et al., 2011; Borg-von Zepelin et al., 1998;). The protein consists of two chains namely A and B. (Fig. 1). Each of this chain consists of 342 amino acid residues. It is considered as one of the key virulence factors that affect the host (Schaller et al., 2000). This enzyme provides the fungus with nutrients and is capable of destroying the host's defense attack. The enzyme is prime responsible for skin infections such as cutaneous candidiosis in human models (Korting et al., 1998). This enzyme performs the key role of penetrating into the tissue during infection in immunocompromised individuals. This enzyme acts attack against the hemoglobin through proteolysis and produces several diverse varieties of antimicrobial hemocidins to fight against diverse variety of microorganisms of the same physiological niche (Schaller et al., 2001). The ligand pepstatin $\mathrm{A}$ is the most potent inhibitor of the aspartyl proteinases (Cadicamo et al., 2013; Koelsch et al., 2000). This ligand shows a very high binding efficiency with the SAP5. A set of strong hydrogen bonds in the SAP5 involves aspartic residues Asp32 and 
Table 1. Details of plant phytochemicals.

\begin{tabular}{|c|c|c|c|c|}
\hline S. No & Compound & IUPAC name & Structure & Chemical formula \\
\hline 1 & Apigenin & $\begin{array}{l}\text { 5,7-dihydroxy-2-(4-hydroxyphenyl)chromen- } \\
\text { 4-one }\end{array}$ & & $\mathrm{C}_{15} \mathrm{H}_{10} \mathrm{O}_{5}$ \\
\hline 2 & Baicalein & 5,6,7-trihydroxy-2-phenylchrom-4-one & & $\mathrm{C}_{15} \mathrm{H}_{10} \mathrm{O}_{5}$ \\
\hline 3 & Cianidanol & $\begin{array}{l}\text { (2R, 3S)-2-(3,4-dihydroxyphenyl)-3,4- } \\
\text { dihydro-2H-chromene-3,5,7-triol }\end{array}$ & & $\mathrm{C}_{15} \mathrm{H}_{14} \mathrm{O}_{6}$ \\
\hline 4 & Curcumin & $\begin{array}{l}\text { (1E, 6E)-1,7bis(4-hydroxy 3-methoxyphenyl) } \\
\text { hepta-1,6-diene-3,5-dione }\end{array}$ & & $\mathrm{C}_{21} \mathrm{H}_{20} \mathrm{O}_{6}$ \\
\hline 5 & Emodin & $\begin{array}{l}\text { 1,3,8-trihydroxy-6-methylanthracene } \\
\text {-9,10-dione }\end{array}$ & & $\mathrm{C}_{15} \mathrm{H}_{10} \mathrm{O}_{5}$ \\
\hline 6 & Equol & $\begin{array}{l}\text { 3-(4-hydroxyphenyl)-3,4-dihydro-2H- } \\
\text { chromen-7-ol }\end{array}$ & & $\mathrm{C}_{15} \mathrm{H}_{14} \mathrm{O}_{3}$ \\
\hline 7 & Genistein & $\begin{array}{c}\text { 5,7-dihydroxy-3-(4-hydroxyphenyl)chromen- } \\
\text { 4-one }\end{array}$ & & $\mathrm{C}_{15} \mathrm{H}_{10} \mathrm{O}_{5}$ \\
\hline
\end{tabular}




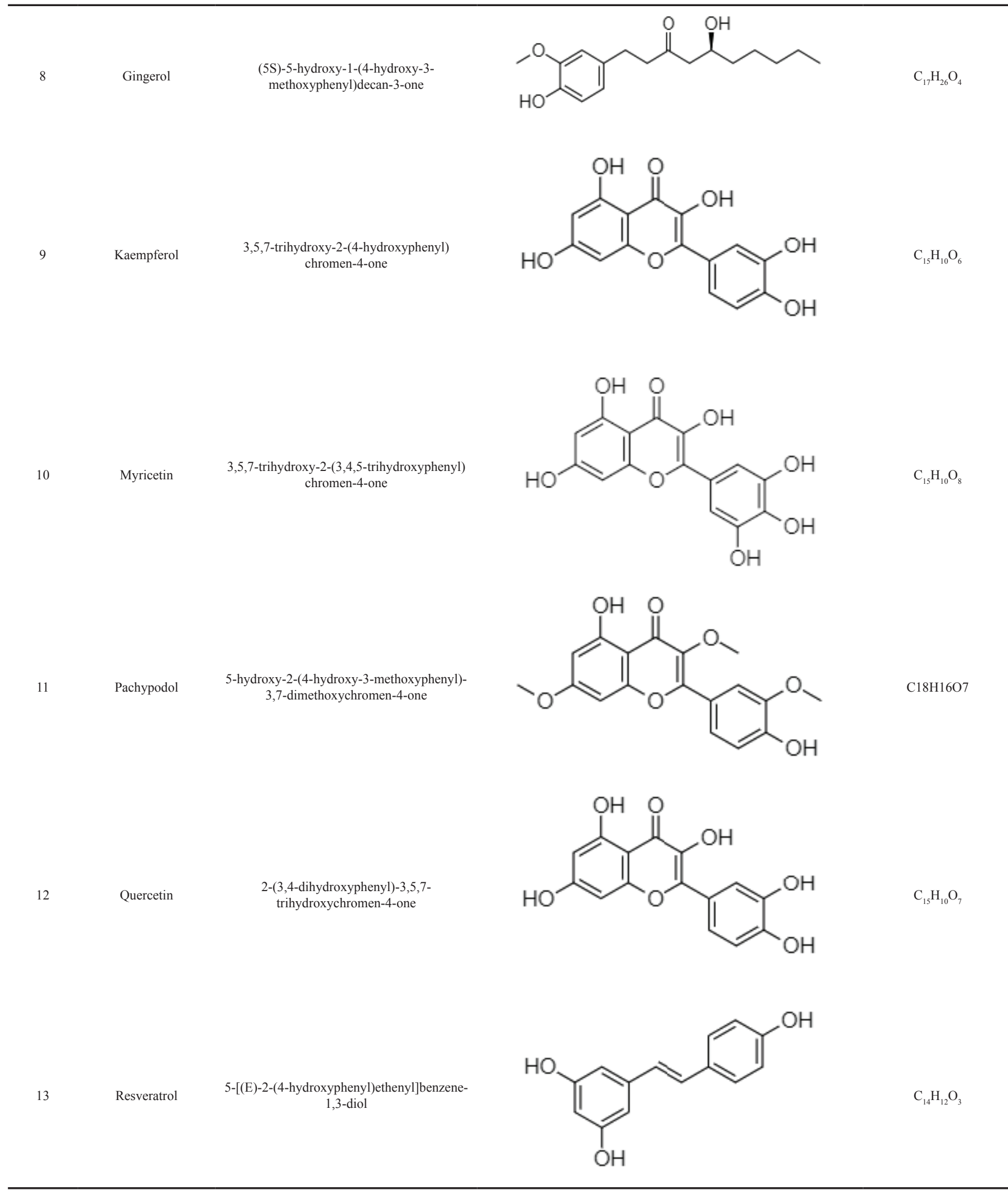




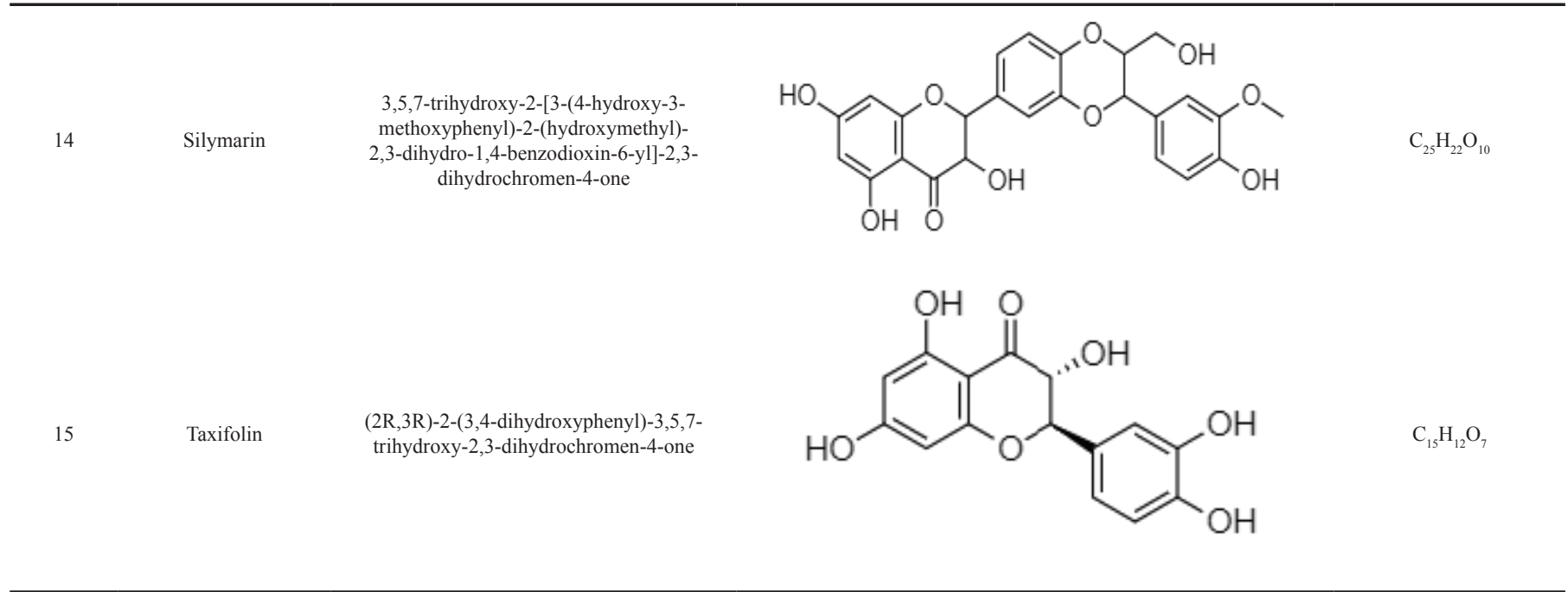

Table 2. Lipinski properties of diverse plant phytochemicals.

\begin{tabular}{|c|c|c|c|c|c|c|}
\hline S. no & $\begin{array}{l}\text { Phytochemical active } \\
\text { compounds }\end{array}$ & $\begin{array}{c}\text { Molecular weight } \\
\text { (<500 Da) }\end{array}$ & $\log P(<5)$ & H-bond donor $(<5)$ & $\begin{array}{c}\text { H-bond acceptor } \\
(<10)\end{array}$ & Molar refractivity $(<130)$ \\
\hline 1 & Apigenin & 270.24 & 2.42 & 3 & 5 & 70.81 \\
\hline 2 & Baicalein & 270.24 & 2.42 & 3 & 5 & 70.81 \\
\hline 3 & Cianidanol & 290.27 & 1.54 & 5 & 6 & 72.62 \\
\hline 4 & Curcumin & 368.38 & 3.37 & 2 & 6 & 102.01 \\
\hline 5 & Emodin & 270.24 & 1.88 & 3 & 5 & 69.48 \\
\hline 6 & Equol & 242.27 & 2.81 & 2 & 3 & 68.15 \\
\hline 7 & Genistein & 270.24 & 2.11 & 3 & 5 & 71.00 \\
\hline 8 & Gingerol & 294.39 & 3.23 & 2 & 4 & 82.75 \\
\hline 9 & Kaempferol & 286.24 & 2.30 & 4 & 6 & 72.38 \\
\hline 10 & Myricetin & 318.23 & 1.71 & 6 & 8 & 75.71 \\
\hline 11 & Pachypodol & 344.32 & 2.70 & 2 & 7 & 88.20 \\
\hline 12 & Quercetin & 302.34 & 2.01 & 5 & 7 & 74.05 \\
\hline 13 & Resvaratrol & 228.24 & 2.97 & 3 & 3 & 66.80 \\
\hline 14 & Silymarin & 482.44 & 2.36 & 5 & 10 & 119.45 \\
\hline 15 & Taxifolin & 304.25 & 1.18 & 5 & 7 & 73.24 \\
\hline
\end{tabular}

Asp218 along with the residues Gly34, Gly85, Asp86, Gly220, and Thr222. These catalytic aspartic residues are highly conserved. The inhibitor binding at residues 83 and 221 are mainly taking part in the hydrogen bonding, thereby forming a network of interactions. The active site region of SAP5 enzyme in complex with inhibitors isovaleric acid and statine retrieved from PDBsum (Fig. 2).

\section{Docking studies using AutoDock 4.2.6}

Docking studies were performed using the phytochemical active compounds mentioned in Table 1 against the enzyme SAP5 using an automated bioinformatics docking tool-AutoDock 4.2.6. AutoDock 4.2.6 is one of most used software by the scientific community to study protein-ligand interactions. The AutoDock 4.2.6 software is based on the principle of Lamarckian genetic algorithm (Meenambiga et al., 2015). The docking interactions between the ligand and the target receptor leading to structure-based drug designing and developmental process are performed using this software. The AutoDock 4.2.6 constitutes two methodologies namely Rapid grid-based energy evaluation and effective search of torsional freedom to accomplish the drug development process (Meenambiga et al., 2015).

\section{Discovery Studio Visualizer 3.1}

Discovery Studio Visualizer 3.1, developed and distributed by Accelrys, is a free software used for visualizing the macromolecule-ligand interactions. This software is used to study the simulation of small molecules and large macromolecules. The main scope of this software includes structure-based design, simulations, ligand design, macromolecule engineering, macromolecule design and validation (tools for antibody design 


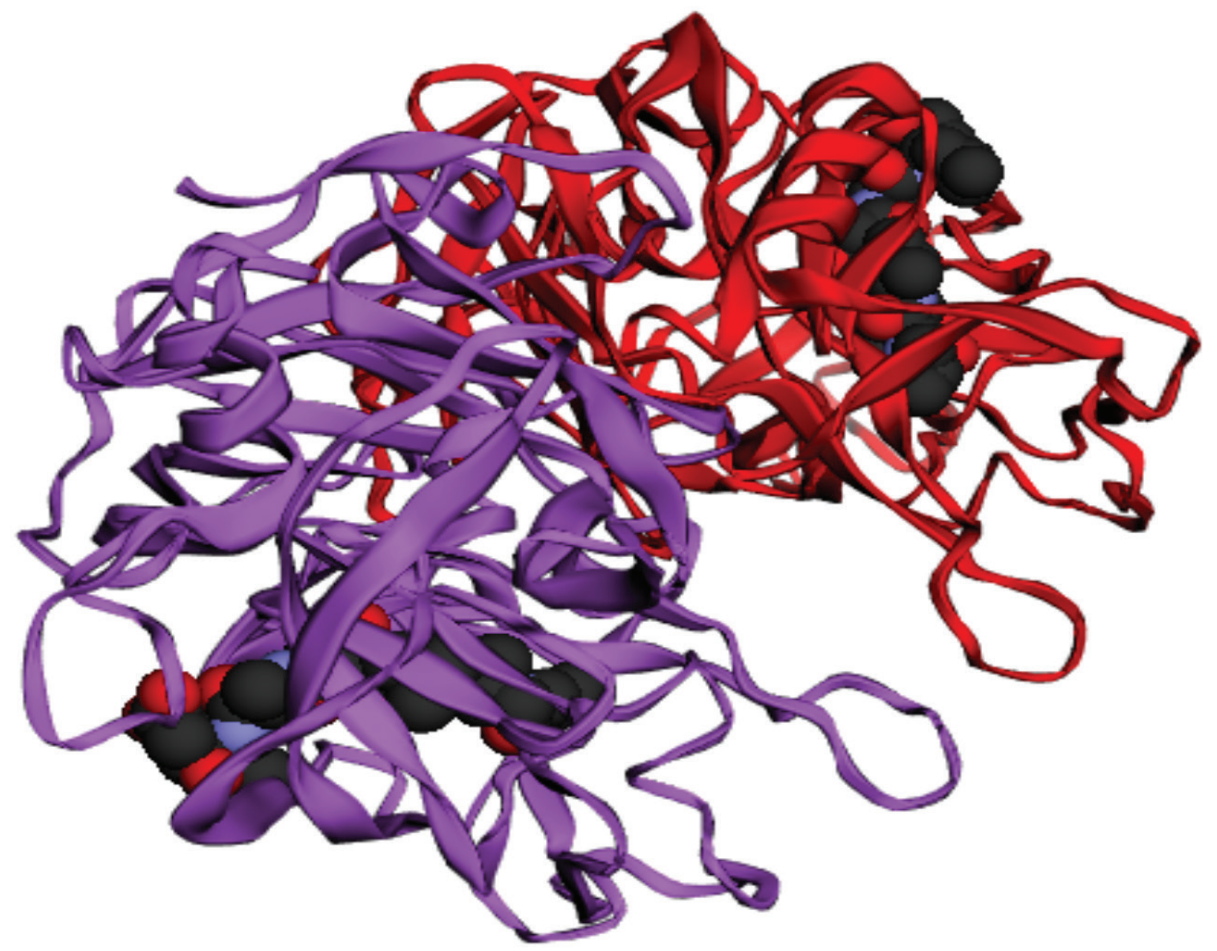

Figure 1. Secreted aspartic proteinase 5 (SAP5). PDB Id: 2QZX with chains A and B in complex with a selective inhibitor.

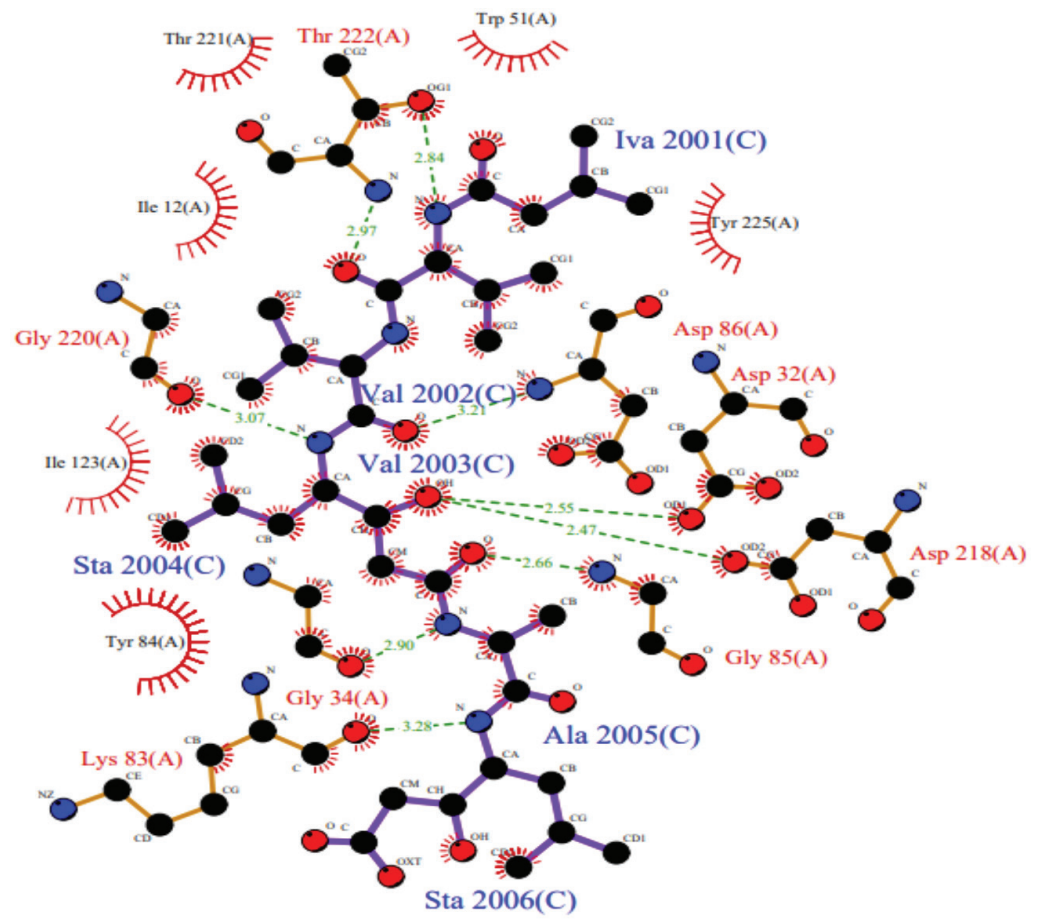

Figure 2. SAP5 in complex with selective inhibitors Isovaleric acid (IVA) and Statine (Sta) showing the active site region.

\& optimization, protein-protein docking), and pharmacophore modeling (Almagro et al., 2011; Corradi et al., 2011; Luu et al., 2011; Sutter et al., 2011). It generates 2D and 3D structures to visualize and analyze the ligand-protein interaction patterns between them.

\section{RESULT AND DISCUSSION}

Globally, about more than 7.5 million people are affected by invasive Candidiasis with approximately $40 \%$ mortality rate. The undesirable side effects, the ineffectiveness and rapid development of resistance by the fungi have exacerbated the need 
for new antifungals (Carmona and Limper, 2017). Plant phenolic compounds possess antifungal properties against $C$. albicans but the knowledge on their mechanism of action is still under scarce (Teodoro et al., 2015a; 2015b). The SAPs are used to degrade foreign tissue and evade the host defense mechanism (Lan et al., 2004). Strains of C. albicans with deleted SAP1, SAP2, and SAP3 are less virulent and caused little damage to the in vitro model (Schaller et al., 1999). 7-hydroxycalamenene and hydroxylated sesquiterpene isolated from Croton cajucara were shown to inhibit SAP (Azevedo et al., 2016). The ethanol extract of Lycopodium cernuum contained triterpene compounds and showed inhibitory effects against $C$. albicans secreted aspartic proteases (Zhang et al., 2002).

In silico analysis of plant compounds was analyzed using Lipinski's rule of five followed by molecular docking studies. All the compounds taken for this study satisfied Lipinski's rule of five and tabulated in Table 2. The binding energy obtained for each ligand, hydrogen bond contacts, and other interactions were tabulated in Table 3. The anthraquinone compound emodin has the highest binding energy with the active site region of SAP5 and the docked confirmation is given in Figure 3. Emodin forms hydrogen bonds with Asp 32, Thr 221, and Thr 222 at the active site region of SAP5 enzyme (Fig. 4). The inhibitory property of emodin on biofilm formation and hyphae development of $C$. albicans was studied by Janeczko et al. (2017). The binding efficiency of equol with the active site of SAP5 enzyme was found to be good with a strong $p i$ it should be italics bond interaction and this compound was proved to have fungicidal activity against $C$. albicans (Lee and Chee, 2010) (Fig. 5). Thus, based on the molecular interactions analyzed, a lead to develop a drug that specifically inhibits the SAP enzyme pathway of $C$. albicans was studied.

The flavonoid compounds pachypodol, baicalein, and apigenin have found to be more potent as SAP5 inhibitors through comparative analysis in this docking experiment (Figs. 6 and 7).

Table 3. Molecular docking analysis of plant phytochemicals against Candida albicans SAP5 enzyme.

\begin{tabular}{|c|c|c|c|c|c|c|}
\hline No. & Compound name & $\begin{array}{l}\text { Binding energy } \\
(\mathrm{kCal} / \mathrm{mol})\end{array}$ & Vanderwaal's interacting residues & $\begin{array}{l}\text { No. of } \mathrm{H} \\
\text { bonds }\end{array}$ & $\begin{array}{l}\mathrm{H} \text { bond interaction } \\
\text { residues }\end{array}$ & $\begin{array}{l}\text { No. of direct contacts } \\
\text { (all polar, non-polar } \\
\text { interactions) }\end{array}$ \\
\hline 1. & APIGENIN & -5.62 & $\begin{array}{l}\text { SER } 35 \text {, ASP } 32 \text {, ASP } 218, \text { ASP } 86 \text {, TYR } 84 \text {, } \\
\text { GLY } 220 \text {, ILE } 12 \text {, THR 222. THR 221, GLY } 85\end{array}$ & 3 & GLY 34, ILE 223, TYR 225 & 13 \\
\hline 2. & BAICALEIN & -5.92 & $\begin{array}{c}\text { ILE 223, TYR 225, THR 221, GLY } 85 \text {, ILE } \\
\text { 305, TYR 84, SER 35, ILE 123, GLY 220, ASP } \\
\text { 218, ASP } 86 \text {, THR } 222\end{array}$ & 2 & ASP 32, GLY 34 & 14 \\
\hline 3. & CATECHINS & -5.35 & $\begin{array}{l}\text { GLY } 34 \text {, SER } 35 \text {, ILE } 123 \text {, TYR } 84 \text {, ILE } 30 \text {, } \\
\text { ARG } 120 \text {, ASP } 86 \text {, THR } 13 \text {, THR 221, LEU } \\
\text { 216, ILE } 305 \text {, GLY } 85\end{array}$ & 5 & $\begin{array}{l}\text { ILE 12, THR 222, ASP } 218, \\
\text { ASP } 32, \text { GLY } 220\end{array}$ & 17 \\
\hline 4. & CURCUMIN & -5.84 & $\begin{array}{c}\text { GLY } 34 \text {, SER } 35 \text {, ILE } 123 \text {, TYR } 84 \text {, ILE } 223 \text {, } \\
\text { GLY 220, THR 222, THR 221, TYR 225, ILE } \\
\text { 305, ASP 86, ARG 120, ILE 12, ASP 308, GLY } \\
\text { 85, ILE } 30 \text {, ASP } 218\end{array}$ & 2 & THR 222, TYR 225 & 19 \\
\hline 5. & EMODIN & -6.35 & $\begin{array}{c}\text { GLY } 85 \text {, ASP } 218 \text {, ILE } 305 \text {, ILE } 12 \text {, ARG } 120 \text {, } \\
\text { THR } 13 \text {, ILE } 30 \text {, ASP } 86 \text {, ILE } 123 \text {, GLY } 220 \text {, } \\
\text { TYR } 84 \text {, SER } 35 \text {, GLY } 34\end{array}$ & 3 & THR 222, THR 221, ASP 32 & 16 \\
\hline 6. & EQUOL & -6.29 & $\begin{array}{l}\text { SER } 35 \text {, ILE } 30 \text {, THR } 222 \text {, ASP } 86, \text { GLY } 220 \text {, } \\
\text { THR } 221 \text {, GLY } 85 \text {, TYR 84, ILE } 123\end{array}$ & 3 & ILE 223, TYR 225, ASP 32 & 12 \\
\hline 7. & GENISTEIN & -3.44 & $\begin{array}{l}\text { THR } 222, \text { ILE } 12, \text { GLY } 85, \text { TYR } 84 \text {, SER } 35 \text {, } \\
\text { GLY } 34, \text { ASP } 218, \text { THR 221, ASP } 86\end{array}$ & 2 & ILE 223, GLY 220 & 13 \\
\hline 8. & GINGEROL & -4.17 & $\begin{array}{c}\text { ASP 218, THR 221, ILE 123, ILE 30, ASP 86, } \\
\text { THR 222, TYR 84, ARG 120, SER 35, GLY } \\
\text { 34, GLY } 85\end{array}$ & 3 & GLY 220, ILE 12, THR 13 & 14 \\
\hline 9. & KAEMPFEROL & -5.40 & $\begin{array}{l}\text { ILE } 223 \text {, TYR } 225 \text {, ILE } 305 \text {, ASP } 218 \text {, ASP } 32, \\
\text { TYR } 84 \text {, SER } 35 \text {, GLY 85, GLY 220, ASP 86, } \\
\text { THR } 13 \text {, ILE } 30, \text { ARG } 120 \text {, ILE } 12\end{array}$ & 3 & THR 222, THR 221, GLY 34 & 17 \\
\hline 10. & MYRICETIN & -5.86 & $\begin{array}{l}\text { TYR } 225 \text {, ILE } 305 \text {, SER } 35 \text {, TYR 84, ASP } 218 \text {, } \\
\text { GLY } 85 \text {, GLY 220, ASP 86, ILE 30, THR 13, } \\
\text { ARG 120, ILE } 12\end{array}$ & 4 & $\begin{array}{c}\text { THR 222, THR } 221, \text { GLY } \\
\text { 34, ASP } 32\end{array}$ & 16 \\
\hline 11. & PACHYPODOL & -6.12 & $\begin{array}{l}\text { TYR 225, THR 222, THR 221, GLY 220, ASP } \\
\text { 86, ASP 218, LEU 216, SER 35, ASP 32, GLY } \\
\text { 85, ILE } 123 \text {, TYR 84, ILE 12, ILE } 223\end{array}$ & 1 & THR 222, THR 221 & 15 \\
\hline 12. & QUERCITIN & -5.57 & $\begin{array}{l}\text { ILE } 305 \text {, TYR } 225 \text {, ILE } 223 \text {, ILE } 12 \text {, ARG } 120 \text {, } \\
\text { THR } 13 \text {, ILE } 30 \text {, GLY 220, ASP 86, THR 221, } \\
\text { TYR } 84 \text {, ASP } 218 \text {, GLY } 34 \text {, GLY } 85\end{array}$ & 2 & GLY 85, THR 222 & 16 \\
\hline 13. & RESVERATOL & -5.61 & $\begin{array}{l}\text { THR 221, GLY 220, ASP } 32 \text {, TYR 84, SER } 35 \text {, } \\
\text { GLY } 85 \text {, ASP 218, ASP 86, THR 222, ILE } 12\end{array}$ & 3 & ILE 223, TYR 225, GLY 34 & 13 \\
\hline 14. & SILIMARIN & 2.04 & $\begin{array}{l}\text { ILE } 30 \text {, ALA } 119 \text {, TRP } 39 \text {, ILE } 123 \text {, TYR } 84 \text {, } \\
\text { GLY } 85 \text {, SER 35, LEU 216, ASP 218, ILE } 305 \text {, } \\
\text { TYR 225, THR 221, ASP 32, GLY 220, THR } \\
\text { 222, ILE } 12, \text { THR } 13\end{array}$ & 3 & LYS 121, GLY 34, ARG 120 & 20 \\
\hline 15. & TAXIFOLIN & -5.57 & $\begin{array}{l}\text { ILE } 223 \text {, THR } 221, \text { ILE } 123, \text { ILE } 30, \text { SER } 35, \\
\text { GLY 34, TYR 84, LEU 216, GLY 86, ASP 86, } \\
\text { GLY 220, TRP 51, ILE } 12\end{array}$ & 2 & ASP 32, THR 222 & 15 \\
\hline
\end{tabular}




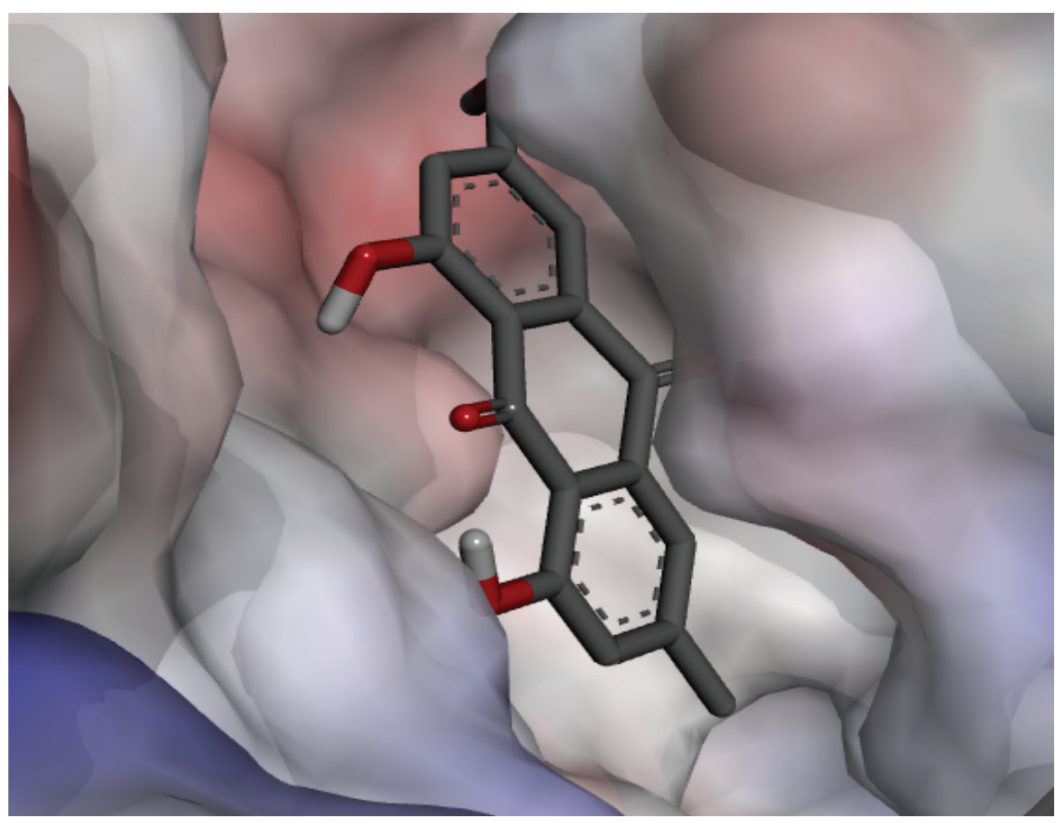

Figure 3. Docked confirmation of the compound emodin with SAP5.
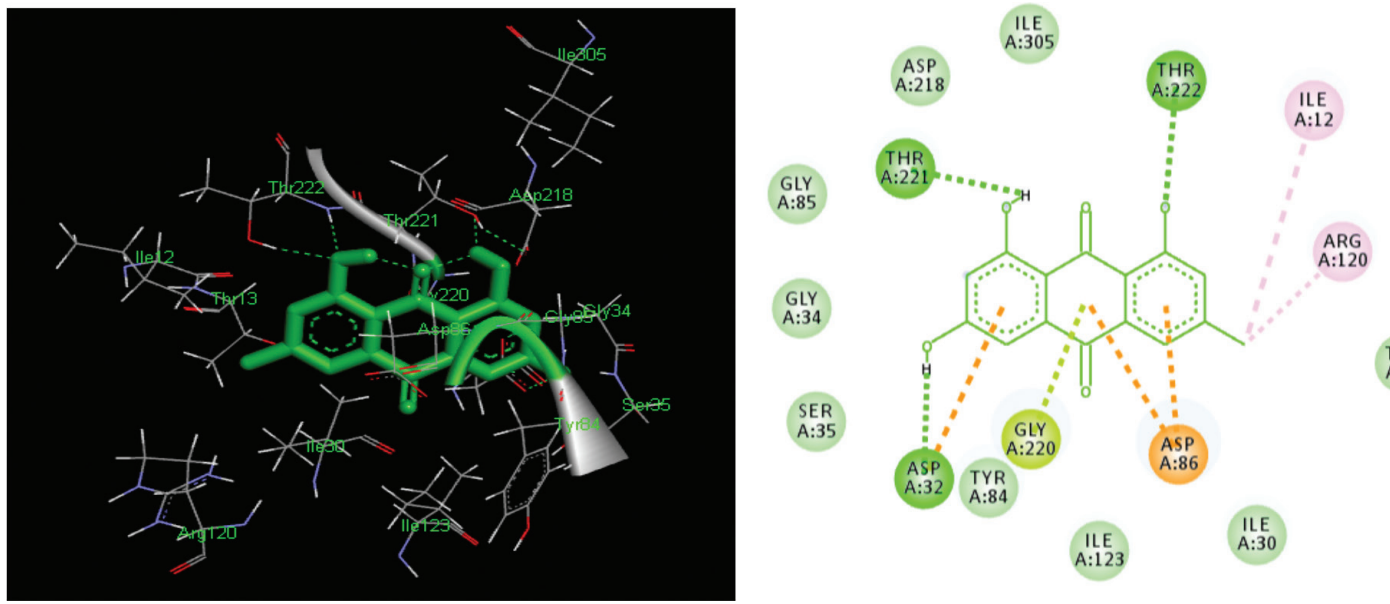

THR

Figure 4. 3D and 2D residual interaction maps of the compound emodin with the active site region of SAP5 enzyme (PDB Id: 2QZX).
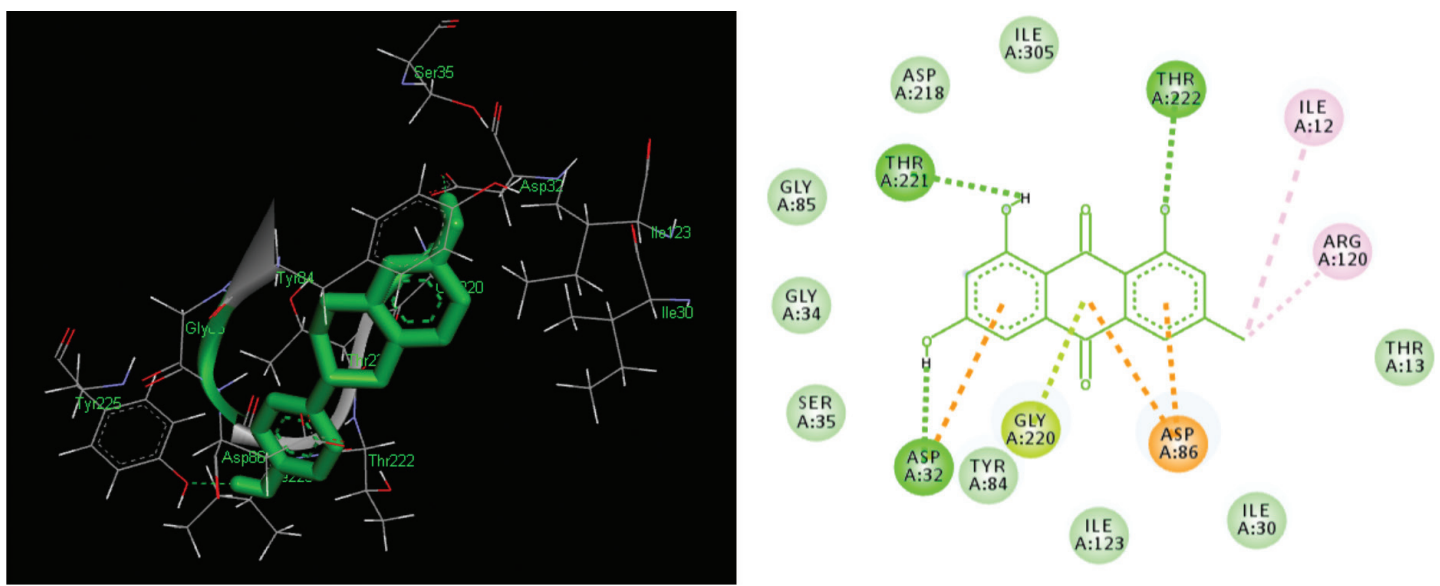

Figure 5. 3D and 2D residual interaction maps of the compound equol with the active site region of SAP5 enzyme (PDB Id: 2QZX). 

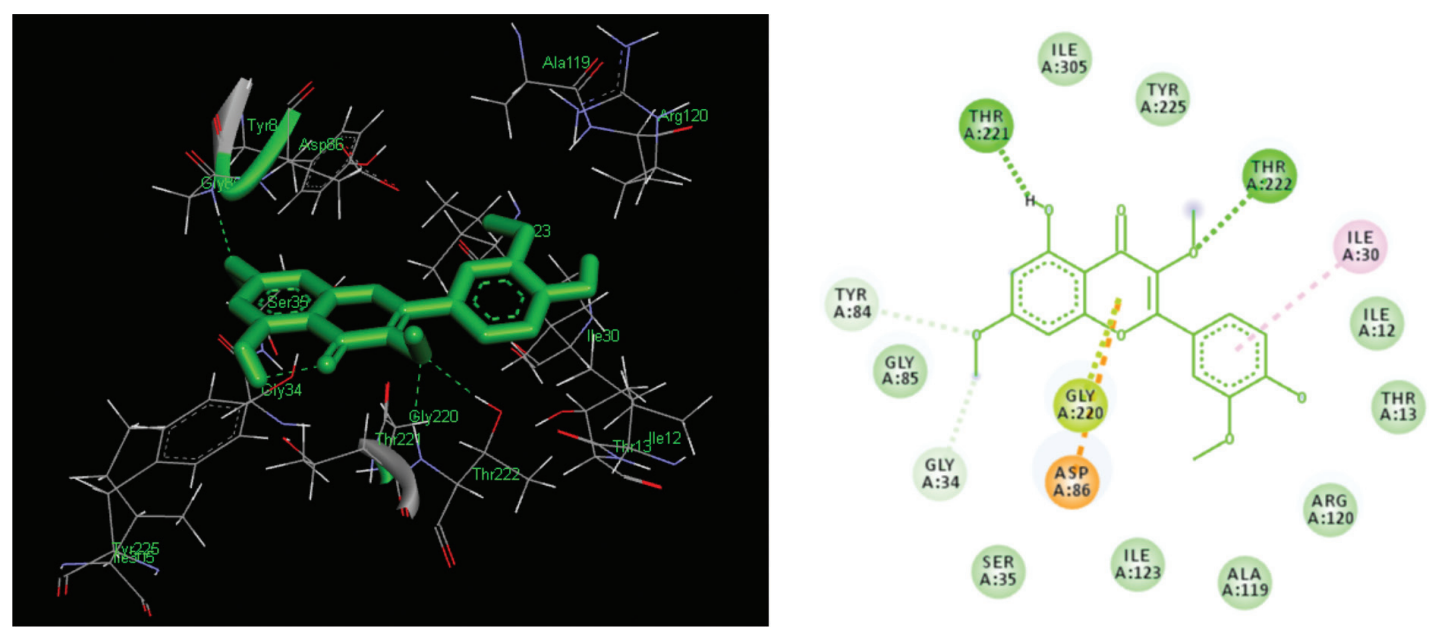

Figure 6. 3D and 2D residual interaction maps of the compound pachypodol with the active site region of SAP5 enzyme (PDB Id: 2QZX).
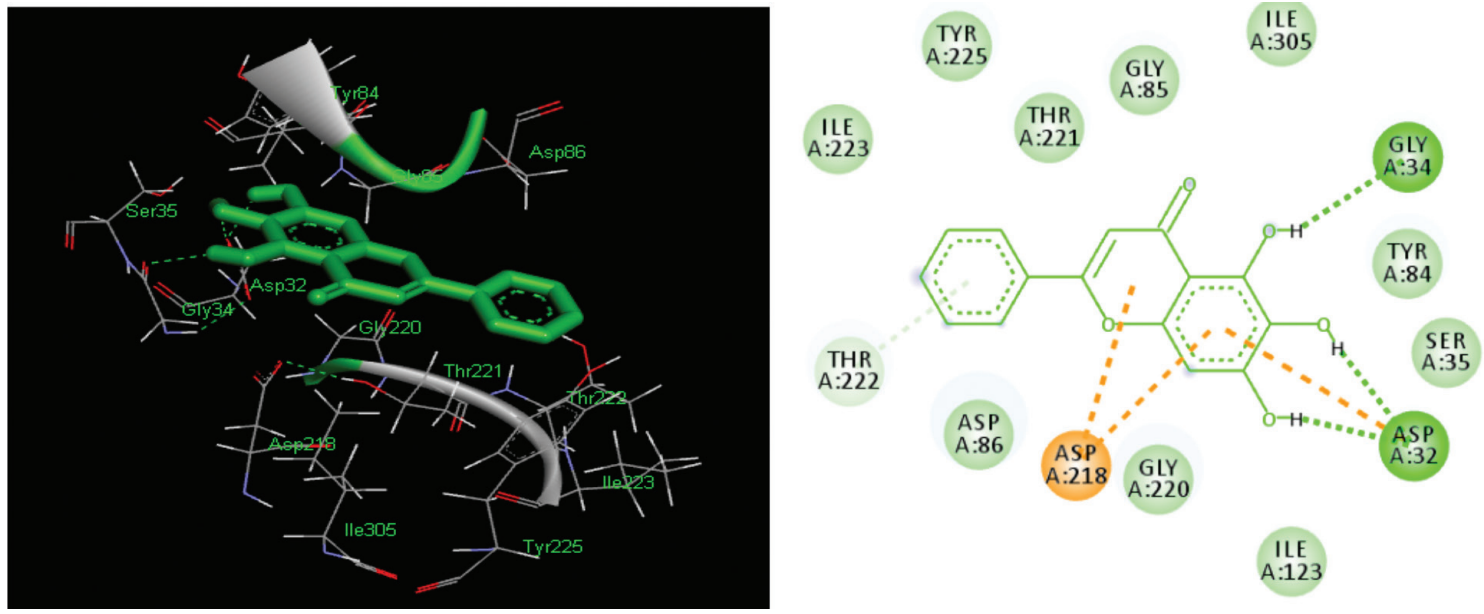

Figure 7. 3D and 2D residual interaction maps of the compound baicalein with the active site region of SAP5 enzyme (PDB Id: 2QZX).

These compounds bind in the active site pocket of SAP5 which is similar to that of the binding of selective inhibitors as shown in Figure 2 (Citoglu et al., 2003; Martins et al., 2008). Docking studies of curcumin with SAP enzyme of $C$. albicans provides us with a knowledge of exact molecular interactions for designing novel curcumin analogues for Candida treatment. Apigenin, a natural flavone has a very good anti-carcinogenic properties and also have proven to inhibit $C$. albicans cell shrinkage, ultimately reducing the biofilm mass (Lee et al., 2018). In vitro analysis of flavonoids such as apigenin and kaempferol showed the reduced adherence of $C$. albicans toward the human epithelial cells (Yordanov et al., 2008). Flavonoids present in the extract of endophytic fungi have also been studied for their inhibitory activity against N-myristoyltransferase enzyme of $C$. albicans through molecular docking analysis (Meenambiga and Rajagopal, 2018). Polyphenols such as taxifolin inhibit the transcriptional factors responsible for transcription of DNA to mRNA. The transcriptional factors that provoke the virulence through hyphal growth are found to be as Tec1 and Rfg1. The Tecl and Rfg1 pathways are inhibited by taxifolin (Mishra et al., 2017). Taxifolin also inhibits the
SAP proteins. Flavonoids heterosides such as quercetin and kaempferol extracts from Equisetum giganteum constitute to the inhibition of oral Candida biofilm (Raut et al., 2016). Thus, these phytochemicals have the potential to inhibit the active site of the SAP5 protein leading to the inhibition of biofilm formation.

\section{CONCLUSION}

The development of natural compounds with biological activity is needed for the treatment of resistant infections. Candida albicans is one such organism with increased virulence and resistance. In the present study, docking results revealed the binding of plant phytochemicals with the secreted aspartic proteinase (SAP) enzyme of $C$. albicans. Among those compounds, "emodin" and "equol" have good binding energies greater than $-6.4 \mathrm{kCal} / \mathrm{mol}$ at the active site region of SAP enzyme and all the phytochemicals satisfy Lipinski's rule which forms the basis for the compound to be used as an oral drug. On the whole, it is concluded that the plant phytochemicals especially flavonoids could be potent drugs for treating Candida infections through SAP enzyme inhibition and this could be further used for research as a pharmacophore for the development of SAP enzyme inhibitors. 


\section{ACKNOWLEDGMENTS}

We sincerely thank the Vels Institute of Science Technology and Advanced Studies management for their support toward the successful completion of the research work.

\section{CONFLICTS OF INTEREST}

The authors declare that they do not have any conflicts of interest.

\section{REFERENCES}

Almagro JC, Beavers MP, Hernandez-Guzman F, Maier J, Shaulsky J, Butenhof K, Labute P, Thorsteinson N, Kelly K, Teplyakov A, Luo J. Antibody modeling assessment. Proteins Struct Funct Bioinf, 2011; 79:3050-66.

Alves LA, Freires ID, Pereira TM, Souza AD, Lima ED, Castro RD. Effect of Schinus terebinthifolius on Candida albicans growth kinetics, cell wall formation and micromorphology. Acta Odontol Scand, 2013; 71(3-4):965-71.

Aoki W, Kitahara N, Miura N, Morisaka H, Yamamoto Y, Kuroda K, Ueda M. Comprehensive characterization of secreted aspartic proteinases encoded by a virulence gene family in Candida albicans. J Biochem, 2011; 150:431-8.

Azevedo MM, Almeida CA, Chaves FC, Rodrigues IA, Bizzo HR, Alviano CS, Alviano DS. 7-hydroxycalamenene effects on secreted aspartic proteases activity and biofilm formation of Candida spp. Pharmacogn Mag, 2016; 12:36.

Barth G, Gaillardin C. Physiology and genetics of the dimorphic fungus Yarrowia lipolytica. FEMS Microbiol Rev, 1997; 19:219-37.

Benet LZ, Hosey CM, Ursu O, Oprea TI. BDDCS, the rule of 5 and drugability. Adv Drug Delivery Rev, 2016; 101:89-98.

Berman HM, Battistuz T, Bhat TN, Bluhm WF, Bourne PE, Burkhardt K, Feng Z, Gilliland GL, Iype L, Jain S, Fagan P. The protein data bank. Acta Cryst D, 2002; 58:899-907.

Borelli C, Ruge E, Lee JH, Schaller M, Vogelsang A, Monod M, Korting HC, Huber R, Maskos K. X-ray structures of Sap1 and Sap5: structural comparison of the secreted aspartic proteinases from Candida albicans. Proteins Struct Funct Bioinf, 2008; 72:1308-19.

Borg-von Zepelin M, Beggah S, Boggian K, Sanglard D, Monod M. The expression of the secreted aspartyl proteinases Sap4 to Sap6 from Candida albicans in murine macrophages. Mol Microbiol, 1998; 28(3):543-54.

Cadicamo CD, Mortier J, Wolber G, Hell M, Heinrich IE, Michel D, Semlin L, Berger U, Korting HC, Höltje HD, Koksch B. Design, synthesis, inhibition studies, and molecular modeling of pepstatin analogues addressing different secreted aspartic proteinases of Candida albicans. Biochem Pharmacol, 2013; 85:881-7.

Cao Y, Dai B, Wang Y, Huang S, Xu Y, Cao Y, Gao P, Zhu Z, Jiang Y. In vitro activity of baicalein against Candida albicans biofilms. Int J Antimicrob Agents, 2008; 32(1):73-7.

Carmona EM, Limper AH. Overview of treatment approaches for fungal infections. Clin Chest Med, 2017; 38:393-402.

Citoglu GS, Sever B, Antus SA, Baitz-Gacs E, Altanlar N. Antifungal flavonoids from Ballota glandulosissima. Pharm Biol, 2003; 41:483-6.

Corradi V, Mancini M, Santucci MA, Carlomagno T, Sanfelice D, Mori M, Vignaroli G, Falchi F, Manetti F, Radi M, Botta M. Computational techniques are valuable tools for the discovery of protein-protein interaction

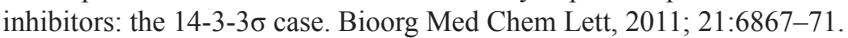

De Viragh PA, Sanglard D, Togni G, Falchetto R, Monod M. Cloning and sequencing of two Candida parapsilosis genes encoding acid proteinases. Microbiology, 1993; 139:335-42.

Gilfillan GD, Sullivan DJ, Haynes K, Parkinson T, Coleman DC, Gow NA. Candida dubliniensis: phylogeny and putative virulence factors. Microbiology, 1998; 144:829-38.
Janeczko M, Masłyk M, Kubiński K, Golczyk H. Emodin, a natural inhibitor of protein kinase CK2, suppresses growth, hyphal development, and biofilm formation of Candida albicans. Yeast, 2017; 34:253-65.

Keller NP, Turner G, Bennett JW. Fungal secondary metabolism-from biochemistry to genomics. Nat Rev Microbiol, 2005; 3:937-47.

Koelsch G, Tang J, Loy JA, Monod M, Jackson K, Foundling SI, Lin X. Enzymic characteristics of secreted aspartic proteinases of Candida albicans. Biochim Biophys Acta Protein Struct Mol Enzymol, 2000; 1480:117-31

Korting HC, Patzak U, Schaller M, Maibach HI. A model of human cutaneous candidosis based on reconstructed human epidermis for the light and electron microscopic study of pathogenesis and treatment. J Infect, 1998; 36:259-67.

Lan CY, Rodarte G, Murillo LA, Jones T, Davis RW, Dungan J, Newport G, Agabian N. Regulatory networks affected by iron availability in Candida albicans. Mol Microbiol. 2004; 53(5):1451-69.

Lee H, Woo ER, Lee DG. Apigenin induces cell shrinkage in Candida albicans by membrane perturbation. FEMS Yeast Res, 2018; 18:foy003.

Lee JA, Chee HY. In vitro antifungal activity of equol agains Candida albicans. Mycobiology, 2010; 38:328-30.

Lipinski CA, Lombardo F, Dominy BW, Feeney PJ. Experimental and computational approaches to estimate solubility and permeability in drug discovery and development settings. Adv Drug Delivery Rev, 2012; 64:4-17.

Luu TT, Malcolm N, Nadassy K. Pharmacophore modeling methods in focused library selection-applications in the context of a new classification scheme. Comb Chem High Throughput Screen, 2011; 14:488-99.

Martins CV, Da Silva DL, Neres AT, Magalhaes TF, Watanabe GA, Modolo LV, Sabino AA, De Fátima A, De Resende MA. Curcumin as a promising antifungal of clinical interest. J Antimicrob Chemother, 2008, $63: 337-9$

Meenambiga SS, Rajagopal K. Antibiofilm activity and molecular docking studies of bioactive secondary metabolites from endophytic fungus Aspergillus nidulans on oral Camndida albicans. J App Pharm Sci, 2018; 8:37-45.

Meenambiga SS, Rajagopal K, Durga R. In silico docking studies on the components of Inonotus sp., a medicinal mushroom against cyclooxygenase-2 enzyme. Asian J Pharm Clin Res, 2015; 8:142-5.

Mishra S, Singh S, Misra K. Restraining pathogenicity in Candida albicans by taxifolin as an inhibitor of Ras1-pka pathway. Mycopathologia, 2017; 182:953-65.

Monod M, Togni G, Hube B, Sanglard D. Multiplicity of genes encoding secreted aspartic proteinases in Candida species. Mol Microbiol, $1994 ; 13: 357-68$

Moore D, Robson GD, Trinci A. Biochemistry and developmental biology of fungi. In: 21st Century Guidebook to Fungi. Cambridge University Press, Cambridge, UK, pp 237-9, 2011.

Naglik JR, Challacombe SJ, Hube B. Candida albicans secreted aspartyl proteinases in virulence and pathogenesis. Microbiol Mol Biol Rev, 2003; 67:400-28.

Raut JS, Karuppayil SM. Phytochemicals as inhibitors of Candida biofilm. Curr Pharm Des, 2016; 22:4111-34.

Schaller M, Januschke E, Schackert C, Woerle B, Korting HC. Different isoforms of secreted aspartyl proteinases (Sap) are expressed by Candida albicans during oral and cutaneous candidosis in vivo. J Med Microbiol, 2001; 50:743-7.

Schaller M, Schackert C, Korting HC, Januschke E, Hube B. Invasion of Candida albicans correlates with expression of secreted aspartic proteinases during experimental infection of human epidermis. J Invest Dermatol, 2000; 114:712-7.

Schaller M, Thoma-Greber E, Korting HC, Hube B, Ollert MW, Schäfer W, Borg-von Zepelin M. In vivo expression and localization of 
Candida albicans secreted aspartyl proteinases during oral candidiasis in HIV-infected patients. J Invest Dermatol, 1999; 112(3):383-6.

Shahzad M, Sherry L, Rajendran R, Edwards CA, Combet E, Ramage G. Utilising polyphenols for the clinical management of Candida albicans biofilms. Int J Antimicrob Agents, 2014; 44(3):269-73.

Sutter J, Li J, Maynard A, Goupil A, Luu T, Nadassy K. New features that improve the pharmacophore tools from Accelrys. Curr Comput Aided Drug Des, 2011; 7:173-80.

Sydnor ER, Perl TM. Hospital epidemiology and infection control in acute-care settings. Clin Microbiol Rev, 2011; 24:141-73.

Teodoro GR, Brighenti FL, Delbem AC, Delbem ÁC, Khouri S, Gontijo AV, Pascoal AC, Salvador MJ, Koga-Ito CY. Antifungal activity of extracts and isolated compounds from Buchenavia tomentosa on Candida albicans and non-albicans. Future Microbiol, 2015a; 10:917-27.

Teodoro GR, Ellepola K, Seneviratne CJ, Koga-Ito CY. Potential use of phenolic acids as anti-Candida agents: a review. Front Microbiol, $2015 b ; 6: 1420$.

Tsang PW, Bandara HM, Fong WP. Purpurin suppresses Candida albicans biofilm formation and hyphal development. PLoS One, 2012; 7(11):e50866.

Xie C, Sun L, Meng L, Wang M, Xu J, Bartlam M, Guo Y. Sesquiterpenes from Carpesium macrocephalum inhibit Candida albicans biofilm formation and dimorphism. Bioorg Med Chem Lett, 2015; 25(22):5409-11.

Yordanov M, Dimitrova P, Patkar S, Saso L, Ivanovska N. Inhibition of Candida albicans extracellular enzyme activity by selected natural substances and their application in Candida infection. Can J Microbiol, 2008; 54:435-40.

Zhang Z, ElSohly HN, Jacob MR, Pasco DS, Walker LA, Clark AM. Natural products inhibiting Candida albicans secreted aspartic proteases from Lycopodium cernuum. J Nat Prod. 2002;65:979-85.

Zaugg C, Borg-von Zepelin M, Reichard U, Sanglard D, Monod M. Secreted aspartic proteinase family of Candida tropicalis. Infect Immun, 2001; 69:405-12.

\section{How to cite this article:}

Meenambiga SS, Venkataraghavan $\mathrm{R}$, Biswal A. In silico analysis of plant phytochemicals against secreted aspartic proteinase enzyme of Candida albicans. J App Pharm Sci, 2018; 8(11): 140-150. 